\author{
St udi a Philosophic a \\ Wr a t i s l a vi e n s i a \\ vol. XVI, fasc. 1 (2021) \\ https://doi.org/10.19195/1895-8001.16.1.1
}

\author{
JERZY LUTY \\ ORCID: 0000-0002-2254-9526 \\ Uniwersytet Wrocławski
}

\title{
Sztuka jako adaptacja: uniwersalizm w estetyce ewolucyjnej*
}

\section{Art as adaptation: Universalism in evolutionary aesthetics}

\begin{abstract}
The paper is a synoptic review of my monograph Art as an adaptation. Universalism in evolutionary aesthetics (2018), which is the analysis of the evolutionary theory of art - a theoretical phenomenon that has been developed in recent years, a discipline that explains the origin of human admiration for beauty and human inclination to create and admire art based on Darwinian theories of natural and sexual selection. The main objective of the paper is to determine to what extent the evolutionary perspective enriches our concept of art and whether naturalization and universalization of the analysis of art can be enlivening for aesthetics in the face of its crisis. On a more general level, the aim of the work is to demonstrate that the use of evolutionary hypotheses in the humanities, based on the achievements of, among others, biology and evolutionary psychology, human behavioural ecology and cognitive archaeology, can become a recipe for the conceptual and identity impasse in the humanities in general. In the paper I make a case for the claim that the evolutionary study of art and artistic behaviour indicates art's inalienability "as a result of the inner human need". It also formulates justified assumptions in a philosophical debate on the existence of aesthetic universals and the credibility of the universalist position in art theory. According to this, art operates as part of a natural, immutable apparatus of sensations, universal to all humans.
\end{abstract}

Keywords: art, adaptation, evolutionary psychology, aesthetic universals, art definitions

\footnotetext{
* Praca powstała w wyniku realizacji projektu badawczego nr 2019/35/B/HS1/02293 finansowanego ze środków Narodowego Centrum Nauki.

Odpowiedź autora na komentarze pozostałych uczestników sympozjum zostanie opublikowana w następnym numerze [red.].
} 
Przedmiotem mojej monografii Sztuka jako adaptacja jest analiza niezwykłego zjawiska teoretycznego, jakim w ostatnich latach stała się estetyka ewolucyjna (ewolucyjna teoria sztuki), dyscyplina, która wyjaśnia pochodzenie ludzkiego podziwu dla piękna i ludzkiej skłonności do tworzenia i podziwiania sztuki, opierając się na darwinowskich teoriach doboru naturalnego i płciowego. Moim celem jest ustalenie, w jakim stopniu perspektywa ewolucyjna wzbogaca nasze pojęcie sztuki oraz czy naturalizacja i uniwersalizacja analizy o sztuce może być ożywcza dla estetyki w obliczu jej postulowanego kryzysu (Welsch, Baudrillard, Kuspit). Na poziomie bardziej ogólnym celem pracy jest wykazanie, że wykorzystanie danych nauk przyrodniczych (hipotez ewolucyjnych) na gruncie nauk humanistycznych, przez odwołanie się do osiągnięć między innymi biologii i psychologii ewolucyjnej czy ekologii behawioralnej człowieka i archeologii kognitywnej, może być receptą na impas pojęciowy i tożsamościowy humanistyki w ogóle.

Estetykę ewolucyjną rozumiem wąsko (w duchu anglosaskim) jako ewolucyjne badanie sztuki; nie należy jej mylić z estetyką ewolucyjną w szerokim sensie, której przedmiotem są ewolucyjne źródła ocen estetycznych w ogóle (środowiska naturalnego, kształtu ciał, kolorów itp.) ani z estetyką środowiskową czy bioestetyką (wywodzącą się z tak zwanego posthumanizmu) oraz neuroestetyką, która poszukuje neurobiologicznych podstaw przeżyć estetycznych (i którą można uznać za naukę pomocniczą estetyki ewolucyjnej). Estetyka ewolucyjna nie tylko powstaje w opozycji do tradycyjnych ujęć i problemów teorii estetycznej (na przykład nie jest obiektocentryczna, nie stosuje kategorii doświadczenia), ale pozostaje też przejawem bardziej ogólnego trendu obserwowanego we współczesnej humanistyce.

\section{Wiek biologii i, ,nowy renesans”}

Trend ten trafnie scharakteryzował filozof, logik i epistemolog Jan Woleński podczas dyskusji panelowej zatytułowanej „Filozofia w XXI wieku”, która obyła się we wrześniu 2012 roku w ramach IX Polskiego Zjazdu Filozoficznego. Krakowski uczony przytoczył w niej dosyć popularny pogląd, mówiący o tym, że o ile w wieku XX najważniejszym naukowym źródłem inspiracji dla filozofii były matematyka i fizyka, o tyle w wieku XXI będzie to z całą pewnością biologia ${ }^{1}$. Sukcesy nauk przyrodniczych, obserwowane zwłaszcza w ostatnich trzydziestu latach, a których efekty widoczne są przede wszystkim w dwóch pierwszych dekadach obecnego stulecia, wydają się potwierdzać tę, na pozór tylko kontrowersyjną, tezę.

W skrócie polegają one na tym, że w wyniku osiągnięcia określonego pułapu wiedzy biologicznej o Homo sapiens (chodzi zwłaszcza o odkrycia z dziedziny genetyki, ale też na przykład rezultaty uzyskane w efekcie zaawansowanego stosowania funkcjonalnego rezonansu magnetycznego — fMRI), a ściślej rzecz biorąc - o źródłach, miejscu i funkcjach zachowań człowieka w ewolucyjnej historii gatunku ludzkiego, nauki przyrodnicze znacznie rozszerzają rozumienie związków człowieka z przyrodą. Ponadto przedstawiciele takich dyscyplin, jak neurobiologia,

1 Panel można obejrzeć w całości na kanale Academicon na platformie YouTube: https://www. youtube.com/watch?v=F8pwPF_C2Gw (dostęp: 28.02.2021). 
paleoantropologia, paleoarcheologia czy biologia i psychologia ewolucyjna żywo interesują się kwestiami podejmowanymi dotąd wyłącznie przez humanistykę i nauki społeczne. Z kolei humaniści (przynajmniej niektórzy) coraz chętniej sięgaja po wyniki badań naukowych, zgodnie ze zdroworozsądkowym przekonaniem, że nie należy ignorować tego, co ma do powiedzenia nauka. Daleko wprawdzie do tego, żeby jednoznacznie stwierdzić, że oto z dnia na dzień przestaje obowiązywać istniejący od dziesięcioleci sztywny podział nauk, który Charles P. Snow w tekście z 1959 roku określił mianem konfliktu kultur: ,naukowej” oraz „,nienaukowej”2. Jest raczej tak, że podział ten istnieje i ma się dobrze, ale coraz częściej zwraca uwagę jego archaiczność. W Dwóch kulturach Snow tak opisywał to zjawisko:

Intelektualiści o literackiej proweniencji — na jednym biegunie, na drugim — naukowcy, z fizykami na czele. A między tymi dwoma biegunami zieje przepaść wzajemnego niezrozumienia, czasami (zwłaszcza wśród młodych) — wrogości i niechęci, lecz nade wszystko braku zrozumienia. Jedni i drudzy mają osobliwie wypaczone wyobrażenia o drugiej stronie. Ich postawy są tak różne, że nie potrafią znaleźć wspólnego języka nawet na poziomie emocjonalnym³

Ów sztywny podział zarysowany przez Snowa dość rzadko próbowano przełamywać. Lekceważenie humanistów przez przedstawicieli nauk ścisłych i przyrodniczych oraz całkowita, wręcz ostentacyjna, ignorancja tych pierwszych wobec ścisłej wiedzy naukowej, nie były tu z pewnością okolicznościami sprzyjającymi. Jak zauważa Snow:

Uczestniczyłem wielokrotnie w spotkaniach ludzi, którzy wedle kryteriów tradycyjnej kultury odebrali staranne wykształcenie i którzy z niemałą lubością wyrażali swoje zdumienie ignorancją naukowców. W kilku przypadkach nie wytrzymałem i zadałem zebranym pytanie, jak wielu z nich potrafiłoby opisać drugie prawo termodynamiki. Powiało chłodem: nikt nie potrafił. A przecież pytałem o coś, co jest naukowym odpowiednikiem pytania: Czy czytałeś któreś z dzieł Szekspira? [...] Sadzę, że nawet gdybym zadał prostsze pytanie - na przykład: co rozumiesz przez masę albo przyspieszenie - które jest naukowym odpowiednikiem pytania „czy umiesz czytać?” — zaledwie jeden na dziesięciu z owych starannie wykształconych ludzi miałby poczucie, że mówimy tym samym językiem ${ }^{4}$.

Z drugiej strony niezwykle trudno byłoby wyobrazić sobie sytuację, w której ktoś próbuje na przykład określić komponenty ludzkiej natury, takie jak: emocje, stany psychiczne czy gusta estetyczne, z zastosowaniem drugiego prawa termodynamiki. Każdą tego rodzaju próbę można by uznać za żart lub w najlepszym razie daleko idaccy redukcjonizm. Nie należałoby traktować tego, rzecz jasna, jako zarzutu wobec teorii fizycznej per se, lecz jako proste stwierdzenie teoretycznej nieadekwatności fizyki do formułowania i rozwiązywania kwestii z zakresu humanistyki. Sądzę, że można zaryzykować twierdzenie, że w ,wieku fizyki” rozdźwięk, nad którym ubolewał Snow, jeśli nie pogłębił się, to z pewnością nie został zniesiony.

Jeżeli z kolei, choćby pobieżnie, prześledzimy dokonania nauk biologicznych oraz ich przenikanie do humanistyki, to okaże się, że na przekór pesymistycznej diagnozie Snowa (oraz w zgodzie z optymistyczną konstatacją Woleńskiego) przyszłość nie rysuje się wcale w ciemnych barwach. Oto bowiem w miejsce dwóch, zwalczających się do tej pory, „kultur”, pojawia się, postulowana przez Snowa, „trzecia kultura”

\footnotetext{
2 C.P. Snow, Dwie kultury, tłum. T. Baszniak, Warszawa 1999.

3 Ibidem, s. 80.

4 Ibidem, s. 89-90.
} 
(określona czasem mianem Nowego Renesansu) ${ }^{5}$, a tworzacy ją „uczeni, myśliciele i badacze świata empirycznego [...] dzięki swym pracom i pisarstwu przejmują rolę tradycyjnej elity intelektualnej w poszukiwaniu odpowiedzi na pytania od zawsze nurtujące ludzkość: czym jest życie, kim jesteśmy i dokąd zmierzamy"6.

Oprócz licznych przedstawicieli science zainteresowanych tematyką ,humanistyczną" (są wśród nich, a jakże: fizycy, astronomowie, biolodzy ewolucyjni, etolodzy, chemicy, meteorolodzy, neurolodzy, bioantropolodzy, paleontolodzy, biogeografowie, badacze technologii, przedstawiciele nauk komputerowych, nauk o poznaniu [cognitive science], filozofowie i matematycy), w obręb „trzeciej kultury” włączają się przedstawiciele nauk humanistycznych. Cechuje ich to, że myślą jak naukowcy; uznają, że świat realny istnieje, a ich celem jest wyjaśnienie i zrozumienie tego świata. Swoje pomysły weryfikuja

w kategoriach logicznej spójności, mocy wyjaśniającej, zgodności z empirycznymi faktami. Nie podporządkowują się bezwarunkowo intelektualnym autorytetom — przyjmują, że każdą koncepcję można podważyć i dopiero dzięki takim wyzwaniom nauka idzie naprzód ${ }^{7}$.

Jednym z pierwszych filozofów, a z pewnością pierwszym zajmującym się estetyką, który zgłosił akces do nowego nurtu, był Denis Dutton. Dla tego filozofa, akademika i aktywisty medialnego, który nie tylko był „prawdziwym mistrzem empirycznych faktów i łączenia naukowych dociekań z estetycznym zrozumieniem", ale też „posiadał szczególną zdolność do splatania niepowiązanych ze sobą dziedzin w jednolitą całość" ", zaangażowanie się w nowy nurt wydawało się naturalne. Twierdził on, że, teoretyzując o sztuce, literaturze, historii czy polityce, ,nie musimy wpadać w pułapkę »społecznej konstrukcji rzeczywistości«, jako jedynej wizji ludzkiego świata", lecz możemy zwrócić się ku naukom przyrodniczym, ponieważ, jak ujął to zgrabnie John Brockman, wszystkie wymienione dziedziny „są produktem interakcji ludzkich umysłów, umysł zaś jest wytworem mózgu, który z kolei jest (częściowo przynajmniej) produktem ludzkiego genomu, czyli czegoś, co powstało w fizycznym procesie ewolucji".

Dutton, jak mało kto przed nim, dostrzegał też krytyczny charakter nowego ruchu, ujawniający się w sprzeciwie wobec sposobu uprawiania tradycyjnej humanistyki, zwłaszcza studiów kulturoznawczych (culture and arts). Ich przedstawiciele — twierdzi Dutton - zaopatrzeni we własny „slang”, ,,jedynie usiłują naśladować naukę, nie bardzo jednak rozumiejąc całą złożoność naukowego myślenia"10. W Epilogu do Nowego Renesansu formułuje następującą diagnozę: akademicka humanistyka, która zajmuje się ,wyłącznie szukaniem powiązań”, najczęściej po prostu świadomie odrzuca model naukowej refleksji, przez co ulega marginalizacji i traci kontakt z rzeczywistością, tworzac system odcięty od jakichkolwiek ze-

${ }^{5}$ Od tytułu zbioru esejów pod redakcją Johna Brockmana - Nowy Renesans: granice nauki, J. Brockman (red.), tłum. P.J. Szwajcer, A. Eichler, Warszawa 2005.

6 Trzecia kultura, J. Brockman (red.), tłum. P. Amsterdamski et al., Warszawa 1996, s. 15.

7 J. Brockman, Wstep. Nowy Renesans, [w:] Nowy Renesans, s. 16.

8 G.L. Hagberg, Introductory Note: Denis Dutton, editor, „Philosophy and Literature”, Evolutionary Aesthetics: A Special Issue in Memory of Denis Dutton, 38 [1A] (2014), s. iv-vi.

9 J. Brockman, Wstęp. Nowy Renesans, s. 16.

10 D. Dutton, Epilog. Nowy Renesans, [w:] Nowy Renesans, s. 391. 
wnętrznych regulacji czy wymogów, gdzie wszystko jest dozwolone (anything goes). Przy czym dla Duttona ,myślenie [...] tak naprawdę to znacznie więcej niż »szukanie powiązań czegokolwiek z czymkolwiek«”, a „nauka opiera się na niezależnie istniejącej rzeczywistości, na fizycznie i biologicznie ewoluującym Wszechświecie, który jest taki, jaki jest — niezależnie od ludzkiej woli"11.

Zbliżoną diagnozę stanu współczesnej humanistyki wypowiada inny czołowy przedstawiciel Nowego Renesansu, psycholog i kognitywista, Steven Pinker w głośnej książce Tabula rasa. Spory o nature ludzka. Ilustruje ją poprzez symptomatyczny, jego zdaniem, fakt degradacji pozycji społecznej krytyka literackiego, bardzo wyróżnionej jeszcze choćby w czasach Sartre'a (dodajmy dla porządku — również w czasie, gdy C.P. Snow wystąpił ze swoim pamiętnym wykładem w Senate House w Cambridge). Źródeł takiego stanu rzeczy upatruje Pinker w „przyczynkarskim” i nieempirycznym charakterze humanistyki oraz w zasklepianiu się „,kultury literackiej" w paradygmatach Wielkiej Teorii, dekonstrukcjonistycznej postteorii, wszelkich możliwych odmian studiów kulturowych czy różnych wersji społecznego konstruktywizmu. Ponadto powodem tego, że przez ostatnie czterdzieści lat kilkakrotnie zmalała liczba kandydatów na studia humanistyczne, obniżył się prestiż tych studiów oraz gotowość do finansowania ich przez różnego rodzaju gremia i instytucje, jest, zdaniem Pinkera, niczym nieuzasadniony opór humanistów wobec wiedzy ścisłej ${ }^{12}$.

\section{Wpływ darwinizmu}

Obserwowany od prawie trzech dekad sukces paradygmatu ewolucjonistycznego w nauce (obejmującego również pytania, które uchodziły dotąd za domenę „,królowej nauk" - filozofii, niebędącej przecież nauką w sensie ścisłym) jest związany przede wszystkim z dynamicznym rozwojem teorii ewolucji. Idee Darwina, które jeszcze $\mathrm{w}$ połowie ubiegłego wieku pozostawały $\mathrm{w}$ pewnym impasie (to znaczy ograniczały się prawie wyłącznie do nauk przyrodniczych), w ostatnich dziesięcioleciach znalazły potwierdzenie i rozwinięcie między innymi w odkryciach genetyków i paleoarcheologów.

Kamieniami milowymi rozwoju genetyki stały się odkrycia Morgana (chromosomowa teoria dziedziczenia), rozwój genetyki populacyjnej, zidentyfikowanie DNA jako nośnika informacji genetycznej i złamanie kodu genetycznego (nagrodzone Nagrodą Nobla odkrycie Watsona i Cricka z lat pięćdziesiątych XX wieku), zidentyfikowanie odcinków kodujących białka strukturalne, pełniących funkcje regulatorowe czy odcinków niekodujących, rozwój technik szybkiego i taniego sekwencjonowania czy wreszcie zsekwencjonowanie nie tylko pojedynczych genów, ale całych genomów organizmów, między innymi: człowieka (Homo sapiens), szympansa (Pan troglodytes/paniscus), muszki owocówki (Drosophila melanogaster), myszy (Mus musculus) czy znacznych części genomu niektórych gatunków wymarłych, jak choćby neandertalczyka (Homo neanderthalensis). Źródeł sukcesu nowego paradygmatu należy

\footnotetext{
11 Ibidem, s. 393.

12 Por. S. Pinker, Tabula rasa. Spory o naturę ludzka, tłum. A. Nowak, Gdańsk 2005, s. 570-572.
} 
dopatrywać się zarówno w rozwoju genetyki, jak i w wypracowaniu spójnego aparatu pojęciowego całej formacji ewolucyjnej (w tym ewolucyjnych humanistów) ${ }^{13}$.

Teoria ewolucji stanowi fundament współczesnej biologii. Przez półtora wieku jej wiarygodność została przetestowana przez niezliczone grono naukowców, którzy w pełni akceptuja jej słuszność i moc wyjaśniającą. Kontrowersje dotyczą nie tyle faktu zachodzenia ewolucji, ile mechanizmów, którymi się ona kieruje. Teoria ewolucji miała duże znaczenie dla rozwoju współczesnej medycyny, epidemiologii, rolnictwa i farmakologii, od których zależy nasze codzienne życie, oraz dla wielu innych dyscyplin, z naukami humanistycznymi włącznie. Problem z jej społeczną akceptacją polega na tym, że większość ludzi jest niedoinformowana, choć nie bez znaczenia jest też wpływ idei religijnych. Na przykład połowa dorosłych Amerykanów zaprzecza teorii ewolucji jako faktowi naukowemu i fanatycy religijni z tego kraju nieprzerwanie od ponad wieku dążą do ograniczenia lub nawet zakazania nauczania o ewolucji w szkołach publicznych (słynny przypadek okręgu Dover) ${ }^{14}$. Niestety, poważne nieporozumienia na temat twierdzeń teorii ewolucji są rozpowszechnione i szkodliwe nie tylko w społeczeństwie, ale i w środowisku akademickim. Słowo „darwinowski" wciąż bywa synonimem bezwzględnego współzawodnictwa, choć określenia, takie jak: ,przetrwanie najlepiej przystosowanych" (survival of the fittest) ${ }^{15}$ kojarzone z ,areną krwawych walk na kły i pazury" (nature, red in tooth and claw) ${ }^{16}$, determinizm genetyczny czy egoizm, nie pochodzą od samego Darwina.

W toczonej na łamach „Gazety Wyborczej” dyskusji na temat darwinizmu Marcin Ryszkiewicz wyjaśnia niektóre trudności związane z akceptacją teorii ewolucji:

Kiedyś [...] darwinizm był eklektyczną teorią, a Darwin nie zawsze ułatwiał swym zwolennikom i krytykom zadanie. Mieszał poziomy selekcji (w samym tytule O powstawaniu gatunków można dopatrzyć się trzech — od jednostek, przez rasy, po gatunki) i przeprowadzał skomplikowane rozważania, których pobieżni czytelnicy jego dzieł nie byli w stanie do końca zrozumieć. Dziś ewolucjonizm okrzepł, dopracował się precyzyjnych narzędzi badawczych i języka, który dokładnie rozróżnia to, co w pionierskich czasach Darwina skrywały mgliste parabole. Takie pojęcia jak egoizm i altruizm, interes gatunku a interes osobniczy, dobór naturalny a dobór grupowy i wiele innych, które na pozór wydają się proste, mają w ewolucjonizmie specyficzne znaczenia. Ich zrozumienie nie jest proste, a ich używanie w potocznym języku [...] wiąże się z ryzykiem nadinterpretacji lub wręcz fałszowania rzeczywistości ${ }^{17}$.

13 Niewątpliwie wśród tych ostatnich spotyka się też naukowość wątpliwej jakości, rodem z dziewiętnstowiecznych traktatów, w której nie uwzględnia się wielu współczesnych ujęć dostarczanych między innymi przez psychologię ewolucyjną czy ekologię behawioralną człowieka.

14 Por. B. Borczyk, Korzenie wspótczesnego antyewolucjonizmu, [w:] Ewolucja. Filozofia. Religia, D. Leszczyński (red.), (Lectiones \& Acroases Philosophicae III), Wrocław 2010, s. 85-107.

15 Problem z użyciem terminu survival of the fittest, który Darwin zapożyczył od Herberta Spencera, polega na tym, że choć jest ono lepsze od całkowicie błędnego stosowania terminu survival of the strongest (przeżycie najsilniejszych), to wciąż nie oddaje istoty działania procesu ewolucyjnego. Bardziej właściwe jest mówienie o reproduction of the fittest (rozmnażaniu się najlepiej przystosowanych), ponieważ najważniejszym miernikiem sukcesu ewolucyjnego jest wydanie na świat potomstwa (czego samo przeżycie osobników jeszcze nie gwarantuje, choć jest do tego koniecznym warunkiem), co nie zawsze dotyczy osobników najsprawniejszych, lecz na przykład tych, które wykażą się najbardziej ekstrawaganckim pokazem (zgodnie z logiką doboru płciowego).

16 Słynna fraza pochodząca od poety Alfreda Lorda Tennysona, przywołana przez Richarda Dawkinsa na określenie działania doboru naturalnego, zob. R. Dawkins, Samolubny gen, tłum. M. Skoneczny, Warszawa 1996, s. 18.

17 M. Ryszkiewicz, Nie mieszajcie w to Darwina, „Gazeta Wyborcza” 6.02.2013, s. 14. 
Choć darwinowska teoria ewolucji, z pewnymi istotnymi modyfikacjami, jest dzisiaj w naukach przyrodniczych nieomal powszechnie akceptowana, to jej zastosowanie do badania mechanizmów życia społecznego i umysłowego rodzaju ludzkiego napotyka wciąż gwałtowny opór. Choć człowiek podlega niezmiennie procesom ewolucyjnym na wielu poziomach (zarówno genotypowym, jak i fenotypowym), analizowanie go w ten sam sposób, co inne stworzenia przyjmowane jest przez humanistów z rezerwą.

Nie zmienia to faktu, że perspektywa ewolucyjna zatacza coraz szersze kregi. Jej zasięg oddziaływania można zaobserwować w wielu dyscyplinach oraz podejmowanych w ich obrębie zagadnieniach ${ }^{18}$, czyli odpowiednio: w psychologii (emocje, motywacje, agresja, empatia), w socjologii (czynniki spójności społecznej, role społeczne), w antropologii (uniwersalia kulturowe i gatunkowe), w ekonomii (konsumpcja na pokaz), w politologii (natura temperamentów politycznych), w psycholingwistyce (pochodzenie i funkcja języka) czy wreszcie w literaturoznawstwie, krytyce i estetyce (powtarzające się motywy przewodnie i uniwersalia estetyczne). Jeśli dodamy do tego niewzruszone, mogłoby się wydawać, „bastiony” filozofii, która sukcesywnie ustępuje pola wywodzącym się z niej naukom szczegółowym, a więc zagadnienia takie jak: początek i koniec wszechświata, problem struktury świadomości i języka czy problemy aksjologiczne związane z moralnością, religijnością i zmysłem estetycznym, to łatwo dostrzeżemy, jak wszechstronny jest to wpływ.

W ramach aktywności ,trzeciej kultury” mamy do czynienia nie tylko ze wzbogaceniem terminologii (o pojęcia instynktu społecznego, religijnego, moralnego, teorie doboru krewniaczego i altruizmu odwzajemnionego czy teorię inwestycji rodzicielskiej) takich obszarów badań i dyscyplin jak psychologia ewolucyjna czy ekologia behawioralna (a z drugiej strony poszczególnych nauk społecznych), ale również $\mathrm{z}$ powstawaniem zupełnie nowych dyscyplin. Pozostają one w zgodzie z postulatem jedności nauk Snowa i wpisują się w program „trzeciej kultury” Brockmana, realizujac ideę konsiliencji (consilience) nauk humanistycznych i przyrodniczych Edwarda O. Wilsona. Wzbogacają tym samym naszą wiedzę humanistyczną o naturze ludzkiej o element empirycznego dowodu. Nowe dyscypliny to na przykład: neurofilozofia ${ }^{19}$, nauroteologia ${ }^{20}$, neuroetyka ${ }^{21}$, nauroestetyka ${ }^{22}$, a także etyka ewolucyjna ${ }^{23}$ i estetyka ewolucyjna ${ }^{24}$. Powstające w ich obrębie różnego rodzaju hybrydy pojęciowe, które mają często charakter metafory (na przykład: instynkt sztuki ${ }^{25}$,

18 Por. M. Miłkowski, Perspektywy ewolucjonistyczne w badaniach społecznych, [w:] Oprogramowanie rzeczywistości społecznej, M. Gdula, L.M. Nijakowski (red.), Warszawa 2014, s. 185-208.

19 Por. P.S. Churchland, Neurophilosophy: Toward a Unified Science of the Mind-Brain, Cambridge, Mass. 1989.

20 Por. P. McNamara, The Neuroscience of Religious Experience, Cambridge 2009.

21 Por. J. Vetulani, Mózg: fascynacje, problemy, tajemnice, Kraków 2010.

22 Por. S. Zeki, Inner Vision. An Exploration of Art and the Brain, Oxford 1999.

23 Por. M. Weiss, Etyka a ewolucja. Metaetyczny kontekst etyki ewolucyjnej, Poznań 2011.

${ }^{24}$ Por. J. Luty, Estetyka ewolucyjna, „Biuletyn Polskiego Towarzystwa Estetycznego” 18 (2011), s. $16-17$.

25 Por. E. Dissanayake, Homo Aestheticus: Where Art Comes From and Why; eadem, Art and Intimacy. How the Arts Began, Seattle 2000; D. Dutton, Instynkt sztuki. Piękno, zachwyt i ewolucja człowieka, tłum. J. Luty, Kraków 2019. 
gen języka ${ }^{26}$ czy gen Boga ${ }^{27}$, co jest również źródłem wielu kontrowersji), oferują jednak zazwyczaj solidnie wyselekcjonowaną, rzetelnie uargumentowaną i sprawdzalną wiedzę empiryczną.

\section{Adaptacja i sztuka. Koncepcja i struktura}

Rosnąca popularność ewolucjonizmu oraz rozwój evolutionary studies w naukach humanistycznych, w tym również w naukach o sztuce (E. Dissanayake, G. Miller, S. Pinker, J. Carroll, R. Storey, J. Gottschall, D.S. Wilson, B. Boyd, D. Dutton) sprawiają, że pojawia się potrzeba opisu ich ram pojęciowych. W swojej monografii zajmuję się zatem najbardziej charakterystycznymi i, moim zdaniem, najbardziej istotnymi momentami ekspansji teorii Darwina na tereny filozoficznej refleksji nad sztuką.

Kluczowe dla zrozumienia istoty sporów wokół adaptacyjnej funkcji sztuki jest pojęcie adaptacji biologicznej ${ }^{28}$. Funkcjonuje ono w dyskursie ewolucjonistycznym od dawna (w biologii ewolucyjnej, ale też w socjobiologii i później w psychologii ewolucyjnej), stanowi też przedmiot tak zwanego sporu o adaptacjonizm w naukach ewolucyjnych. Poddając je analizie na równi z pojęciem sztuki, staram się jednocześnie pokazać, jak zmienia się teoretyczne ujęcie sztuki w wyniku stopniowego przejścia od perspektywy estetycznej do naturalistycznej i natywistycznej, pod wpływem ustaleń ewolucyjnych nauk o człowieku. Ta zmiana perspektyw powoduje, że sztuka przestaje być postrzegana wyłącznie jako nabyta ludzka własność, mająca swe źródło w kulturze, a zaczyna jawić się również jako niezbywalna cecha ludzkiego wyposażenia umysłowego, ukształtowana w wyniku działania procesów ewolucyjnych. Ponieważ akcenty uniwersalistyczne i naturalistyczne są obecne w samej teorii estetycznej od jej początków, uważam, że teoretycznie dojrzały wyraz otrzymują one w zmodyfikowanej przez Duttona Searle'owskiej wersji definicji skupiskowej (cluster definition of art), składającej się ze zbioru kryteriów rozpoznawczych (recognition criteria), i stanowiącej propozycję neutralnej podstawy teoretycznej do spekulacji na temat sztuki jako uniwersalnego ludzkiego fenomenu, swoistego rodzaju naturalnego ${ }^{29}$. Jak pisze Dutton w rozdziale 3 Instynktu sztuki, zatytułowanym Co jest sztuka?: „To, czego potrzebuje filozofia sztuki, to podejścia, które zacznie traktować sztukę jako pole działań, obiektów i doświadczeń naturalnie [wyr. - J.L.] pojawiających się w ludzkim życiu"30.

26 Por. S. Pinker, P. Bloom, Natural language and natural selection, „Behavioral and Brain Sciences" 13 [4] (1999), s. 707-784; R. Dunbar, Pchty, plotki i ewolucja języka, tłum. T. Pańkowski, Warszawa 2009.

27 Por. D. Hamer, The God Gene: How Faith Is Hardwired into Our Genes, New York 2004.

28 Por. J. Luty, Estetyka ewolucyjna: sztuka jako adaptacja w ujęciu międzykulturowym, „Estetyka i Krytyka" 21 (2011), s. 99-112.

29 Pokazuję też, jak definicja skupiskowa może stanowić poręczne narzędzie do analizy sztuki w kategoriach homeostatycznej wiązki własności (rodzaje naturalne R. Boyda); zob. rozdział 4.

30 D. Dutton, Instynkt sztuki, s. 98. 
Rozważam też zasadniczą, nieustannie dyskutowaną w estetyce ewolucyjnej kwestię, a mianowicie: czy sztuka ma wartość adaptacyjną w sensie biologicznym? Spór ten jest o tyle interesujący, że jego rezultaty zależą w dużej mierze od ustaleń wyprowadzanych nieustannie z odkryć naukowych, a także podlegają mocno kontrintuicyjnej logice praw rządzących procesem ewolucyjnym, w tym zwłaszcza zasadzie ewolucyjnej inercji. Zasada ta mówi o tym, że większość ewolucyjnych adaptacji ludzkiego umysłu jest już w dzisiejszej rzeczywistości (zindustrializowanej, zmediatyzowanej, zindywidualizowanej, kapitalistycznej globalnej wioski) nieadaptacyjna.

Analiza pojęcia ,adaptacja” oraz sposobu jego funkcjonowania w biologii ewolucyjnej może odbywać się jedynie w kontekście klasycznej teorii doboru naturalnego (Darwin, Wallace) ${ }^{31}$. Istotne jest przy tym odwołanie się do poglądów Williamsa na temat właściwych kryteriów adaptacji ewolucyjnej ${ }^{32}$, propozycji: Triversa teorii altruizmu odwzajemnionego i inwestycji rodzicielskiej ${ }^{33}$, Dawkinsa — teorii samolubnego genu i fenotypu rozszerzonego ${ }^{34}$ oraz nowego wymiaru sporu o hiperadaptacjonizm, zainicjowanego przez Goulda i Lewontina tekstem Spandrels of San Marco z 1979 roku $^{35}$. Ostatnie trzy dekady to narodziny i niebywały sukces paradygmatu $^{36}$ psychologii ewolucyjnej (niekiedy traktuje się psychologię ewolucyjną jako heurystykę, na przykład w kognitywnie zorientowanym literaturoznawstwie $)^{37}$ oraz jego różnorodny wpływ na nauki społeczne i humanistyczne. Wpływ ten można odnieść do szerokiego spektrum zagadnien ${ }^{38}$, między innymi takich jak: zachowania aspołeczne $^{39}$, funkcje języka ${ }^{40}$, rola plotki w rozwoju języka i utrzymywaniu spójności społecznej ${ }^{41}$, rola oszustw i samooszukiwania się ${ }^{42}$, studia nad seksualnością ${ }^{43}$, strategie reprodukcyjne ${ }^{44}$, wpływ modularnej teorii umysłu i poznania rozdzielnego

31 Por. K. Darwin, O powstawaniu gatunków, tłum. S. Dickstein, J. Nusbaum, Warszawa 2009; A.R. Wallace, Contributions to the Theory of Natural Selection, London 1870.

32 Por. G.C. Williams, Adaptation and Natural Selection: A critique of Some Current Evolutionary Thought, Princeton 1966; D. Buss, Psychologia ewolucyjna, tłum. M. Orski, Gdańsk 2001, s. 36-38.

33 Por. R. Trivers, The Evolution of Reciprocal Altruism, „The Quarterly Review of Biology" 46 [1] (1971), s. 35-57; R. Dawkins, Samolobny gen.

${ }^{34}$ Por. R. Dawkins, Fenotyp rozszerzony. Dalekosiężny gen, tłum. J. Gliwicz, Warszawa 2007.

35 Por. H. Cronin, Adaptation: A Critique of Some Current Evolutionary Thought, ,The Quarterly Review of Biology" 80 [1] (2005), s. 19-26.

36 Por. M. Hohol, Wyjasnić umysł. Struktura teorii neurokognitywnych, Kraków 2013, s. 104-125.

37 Por. K. Mellmann, Evolutionary Psychology as a Heuristic in Literary Studies, [w:] The Evolution of Literature. Legacies of Darwin in European Cultures (Internationale Forschungen zur Allgemeinen und Vergleichenden Literaturwissenschaft 152), N. Saul, S.J. James (eds.), Rodopi 2011, s. $299-317$.

38 Więcej na temat ogólnie pojętego wpływu perspektywy ewolucyjnej na dyscypliny o ,proweniencji literackiej" (określenie Snowa) piszę w kolejnym rozdziale.

39 Por. M. Daly, M. Wilson, Homicide, New York 1988.

40 Por. S. Pinker, P. Bloom, Natural language and natural selection; R. Dunbar, Pchty, plotki a ewolucja języka, tłum. T. Pańkowski, Warszawa 2009; P. Żywiczyński, S. Wacewicz, Ewolucja języka. W strone hipotez gesturalnych, Toruń 2015.

41 Por. R. Dunbar, Pchty, plotki a ewolucja języka.

42 Por. R. Trivers, Deceit and Self-Deception. Fooling Yourself the Better to Fool Others, London 2011.

43 Por. C. Salmon, D. Symons, Warrior Lovers: Erotic Fiction, Evolution and Female Sexuality, London 2001.

44 Por. D. Buss, Psychologia ewolucyjna; R. Dunbar, Pchty, plotki a ewolucja języka; Biologia atrakcyjności człowieka, B. Pawłowski (red.), Warszawa 2009. 
na rozwój kultury (decoupled cognition ${ }^{45}$, zjawisko gwałtu ${ }^{46}$, naturalne źródła religii ${ }^{47}$, naturalne źródła moralności ${ }^{48}$ oraz, last but not least, w refleksji o sztuce $^{49}$.

\section{State of art}

W obrębie ewolucyjnych badań nad sztuką sformułowano wiele odważnych hipotez. Najżywiej dyskutowany problem dotyczy funkcji przystosowawczej sztuki czy sztuka w swych różnych formach powstała jako adaptacja biologiczna, czy też należałoby uznać ją raczej za nowoczesny produkt uboczny adaptacji? W dyskusji tej można wyróżnić kilka stanowisk. Sa to: hipoteza pendentywu (spandrel) ${ }^{50}$ albo produktu ubocznego, czyli metafora sernika dla umysłu (cheesecake for the mind $)^{51}$; hipoteza silnika spalinowego ${ }^{52}$. Wymienić należy także: koncepcję ekspozycji seksualnej (sexual display), zwaną teorią kosztownego sygnalizowania ${ }^{53}$, koncepcje gry poznawczej (cognitive play) ${ }^{54}$, koncepcję intensyfikatora doznań i regulatora skomplikowanej organizacji psychologicznej — uznająca sztukę za środek psychologicznego uporządkowania ${ }^{55}$, koncepcję sztuki jako środka tworzenia spójności społecznej ${ }^{56}$.

Steven Pinker hipotetyzuje na przykład, że estetyczna wrażliwość jest zaledwie efektem ubocznym mocy poznawczych, które wyewoluowały, aby wypełnić bardziej praktyczne funkcje (takie jak: pogoń za statusem, estetyczna przyjemność

45 Por. L. Cosmides, J. Tooby, Evolutionary psychology: Foundational papers, Cambridge, Mass. 2000; S. Pinker, Jak działa umyst.

46 Por. R. Thornhill, C.T. Palmer, Rape: A Natural History of Biological Bases of Coercion, Cambridge, Mass. 2000.

47 Por. P. Boyer, I człowiek stworzył bogów... Jak powstała religia?, tłum. K. Szeżyńska-Maćkowiak, Warszawa 2005; R. Dawkins, Fenotyp rozszerzony; D. Dennett, Odczarowanie. Religia jako zjawisko naturalne, tłum. B. Stanosz, Warszawa 2008.

48 Por. M. Ridley, O pochodzeniu cnoty, tłum. M. Koraszewska, Poznań 2000; M. Hauser, Moral Minds: How Nature Designed a Universal Sense of Right and Wrong, New York 2006; P.S. Churchland, Braintrust: What Neuroscience Tells Us about Morality, Princeton 2011; J. Vetulani, Mózg.

49 Warto dodać, że sztuka jako zbiór istotnych ewolucyjnie ludzkich praktyk jest przedmiotem refleksji wielu przedstawicieli nauk biologicznych, którzy umieszczają ją w orbicie w swych zainteresowań, traktując ją jako potencjalną adaptację. Piszą o niej: S. Pinker, M. Gazzaniga, E.O. Wilson, G. Miller, D. Buss, J. Tooby I L. Cosmides, D. Morris, G. Orians i in.

${ }^{50}$ Por S.J. Gould, R.C. Lewontin, Pendentywy w katedrze św. Marka a paradygmat Panglossa. Krytyka programu adaptacyjnego, tłum. K. Bielecka, „Przegląd Filozoficzno-Literacki” 2/3 (2011), s. 63-85; S. Davies, Why Art Is not a Spandrel, „British Journal of Aesthetics” 50 [4] (2010), s. 333-341.

51 Por. S. Pinker, Jak działa umyst.

52 Por. D. Dutton, Instynkt sztuki.

53 Por. G. Miller, Umyst w zalotach: jak wybory seksualne kształtowały nature człowieka, tłum. M. Koraszewska, Poznań 2004; E. Voland, Preferencje estetyczne w świecie artefaktów — przystosowanie do osądu „uczciwych sygnałów”, tłum. J. Luty, „Przegląd Filozoficzno-Literacki” 2/3 (2011), s. 299-323; A. Zahavi, A. Zahavi The Handicap Principle - A Missing Piece of Darwin's Puzzle, New York 1997.

54 Por. B. Boyd, On the Origin of Stories: Evolution, Cognition, and Fiction, Cambridge, Mass. 2009.

55 Por. E. Dissanayake, Homo Aestheticus; J. Carroll, Reading Human Nature: Literary Darwinism in Theory and Practice, Albany, NY 2011; D. Dutton, Instynkt sztuki.

56 Por. K. Coe, The Ancestress Hypothesis, New York 2003; N.E. Aiken, The Biological Origins of Art, Westport, CT 1998; E. Dissanayake Art and Intimacy. How the Arts Began, Seattle 2000.

Studia Philosophica Wratislaviensia vol. XVI, fasc. 1, 2021

(C) for this edition by CNS 
doświadczania otoczenia i zdolność do wytwarzania przedmiotów praktycznego użytku ${ }^{57}$; jednak dopuszcza on również możliwość, iż opowiadanie historii może mieć funkcję adaptacyjną, dostarcza bowiem informacji dotyczacych problemów istotnych z punktu widzenia poznawczego ${ }^{58}$. Geoffrey Miller jest przekonany, że wytwory artystyczne spełniały od zawsze funkcję pokazu sprawności, ekspozycji dobrych genów na potrzeby doboru płciowego ${ }^{59}$. Brian Boyd ${ }^{60}$ utrzymuje, że dzieła sztuki są formami gry poznawczej, która poprawia rozpoznawanie wzorców, z kolei Ellen Dissanayake ${ }^{61}$ (wraz Boydem) uważa, że sztuka zapewniała środki do tworzenia wspólnej tożsamości społecznej. Dissanayake, Joseph Carroll ${ }^{62}$ i Dutton ${ }^{63}$ utrzymują, że sztuka pomaga uporządkować umysł ludzki, ponieważ dostarcza estetycznie i emocjonalnie zmodyfikowanych form relacjom pomiędzy elementami ludzkich doświadczeń. Pogląd, że sztuka funkcjonuje jako środek psychologicznego uporządkowania, wynika z poprzednich twierdzeń (że sztuka zapewnia istotne poznawczo informacje, umożliwia rozważanie alternatywnych scenariuszy i rozwiązań, wspomaga rozpoznawanie wzorców i służy jako środek do kreowania wspólnej tożsamości społecznej), ale formułuje je na wyższym poziomie ogólności. Dobrze uargumentowana wydaje się hipoteza Millera, zwana też hipotezą kosztownego sygnalizowania, że sztuka może być wykorzystywana jako wskaźnik sprawności (fitness indicator), jednak pod tym względem sztuka nie różniłaby się niczym od innych ludzkich wytworów, takich jak: odzież, biżuteria, piękne budowle czy szybkie samochody. Jak zauważa Carroll, hipoteza, że sztuka umożliwia uporządkowanie umysłu, nie jest nie do pogodzenia z tezą o ekspozycji seksualnej, lecz podporządkowuje pokaz bardziej pierwotnej funkcji przystosowawczej (po prostu podoba się - sygnalizuje fitness, przyciąga uwagę to, co ma wartość adaptacyjną).

Wiarygodność hipotezy mówiącej o tym, że sztuka funkcjonuje jako medium psychologicznego uporządkowania, wynika z dwóch przesłanek: szczególnej dla człowieka potrzeby sztuki oraz posiadania przez niego wyjątkowych mocy poznawczych. Wszystkim zwierzętom, poza ludźmi, świat przedstawia się jako seria ściśle określonych bodźców, uwalniających jedynie wąski repertuar stereotypowych zachowań. Umysłowi ludzkiemu świat jawi się jako nieprzebrany i potencjalnie wprawiający $\mathrm{w}$ zakłopotanie szeroki wachlarz obiektów percepcji, wnioskowań, związków przyczynowych, przypadkowych możliwości, analogii, przeciwieństw oraz hierarchicznych struktur pojęciowych, którymi próbuje to wszystko oplatać. Wysoki poziom inteligencji daje człowiekowi możliwość tworzenia planów, opartych na intelektualnych wyobrażeniach o złożonych związkach, angażowania się w zbiorowe przedsięwzięcia, wymagające wspólnych reprezentacji umysłowych, a co za tym

57 Por. S. Pinker, Jak działa umyst.

58 Por. S. Pinker, Toward a Consilient Study of Literature (review of J. Gottschall \& D. Sloan Wilson, "The Literary Animal: Evolution and the Nature of Narrative”), „Philosophy and Literature” 31, [1] (2007), s. 161-177.

59 Por. G. Miller, Umyst w zalotach.

60 Por. B. Boyd, On the Origin of Stories.

61 Por. E. Dissanayake, Art and Intimacy.

62 Por. J. Carroll, An Evolutionary Paradigm for Literary Study, ,Style” 42 [2] (2008), s. 103-135.

63 D. Dutton, Instynkt sztuki. 
idzie do produkowania nowatorskich rozwiązań problemów adaptacyjnych. Jednak człowiek nie tylko nie działa automatycznie, ale też nie działa na podstawie czysto racjonalnego namysłu nad środkami i celami. Zazwyczaj kieruje się intuicją, a większości jego działań towarzyszą emocje. Tłumaczy to fakt, że we wszystkich znanych społecznościach ludzie reguluja swoje zachowania przez idee i wartości wyrażone w dziełach sztuki. Sztuki, której domeną są emocje i która „może pocieszyć w czasie kryzysów życiowych, może ukoić nerwy, pomóc w osiągnięciu psychologicznego katharsis, wyzwalać emocje, które oczyszczają umysł i karmią duszę"64.

Kolejnym, obok adaptacji, pojęciem kluczowym dla moich rozważań jest pojęcie sztuki. Spośród możliwych do przyjęcia stanowisk teoretycznych w kwestii definicji sztuki, biorąc pod uwagę historię samego pojęcia, a także uniwersalny charakter fenomenu sztuki — za Brianem Boydem można wymienić następujące z nich (droga wiedzie od refleksji estetycznej do biokulturowej):

1. sztuka jest kategorią mało sensowną, pozbawioną znaczenia (pojęcie sztuki nie jest spójne, nie odnosi się do żadnej określonej klasy zjawisk);

2. nie istnieje uniwersalne pojęcie sztuki, lecz jedynie zachodnie jej pojęcie, które powstało w XVIII wieku w Europie;

3. sztuka może być w całości opisana, zbadana przez pryzmat kultury, tradycji kulturowej czy kulturowej różnorodności;

4. sztuka może być opisana w odniesieniu do jej funkcji lub zespołu funkcji (teorie: mimetyczna, ekspresjonistyczna, komunikatywna, instytucjonalna teoria sztuki);

5. stanowisko przejściowe między podejściem kulturowym a ewolucyjnym, uwzględniające jako ustalenia wstępne dane nauk ewolucyjnych o człowieku, zgodnie z którym istnieją przesłanki, aby uznać sztukę w takim samym stopniu za wytwór kultury, jak też biologii człowieka:

a) sztuka jest czymś uniwersalnym w społecznościach ludzkich,

b) przetrwała kilkadziesiąt tysięcy pokoleń,

c) mimo wielkiej różnorodności i kombinacji zachowań sztuka we wszystkich znanych społecznościach przyjmuje te same główne formy (muzyka i taniec; manualne tworzenie wizualnych kompozycji; opowiadanie historii i poezja),

d) zwykle wiąże się z wysokimi kosztami czasu, energii i zasobów,

e) wywołuje silne emocje, które są ewolucyjnymi wskaźnikami, że coś ma znaczenie dla organizmu,

f) rozwija się niezawodnie u wszystkich normalnych ludzi, bez specjalnego treningu, inaczej niż umiejętności czysto kulturowe, takie jak czytanie, pisanie czy nauka; sztuka pojawia się na wczesnym etapie ewolucyjnego rozwoju (niemowlęta reagują radośnie na kołysanki i spontanicznie bawią się kolorami, kształtami, rytmami, dźwiękami, słowami i opowieściami) i daje podstawę do sformułowania hipotezy, że być może:

6. sztuka (zachowanie artystyczne i artyfikacyjne) ma wartość adaptacyjną, daje przewage przystosowawczą nad organizmami, którzy tego zachowania nie wykazują, wspomaga organizm w dobrze naturalnym lub

64 Ibidem, s. 155.

Studia Philosophica Wratislaviensia vol. XVI, fasc. 1, 2021

(C) for this edition by CNS 
7. sztuka nie jest produktem doboru naturalnego, nie sprzyja przetrwaniu, stanowi natomiast efekt uboczny doboru płciowego (jest ekstrawaganckim, bezużytecznym pokazem, kosztownym sygnałem, ornamentem w grze o przyciągnięcie potencjalnego partnera reprodukcyjnego lub partnerki reprodukcyjnej) ${ }^{65}$ albo

8. sztuka jest produktem ubocznym innych ewolucyjnych adaptacji ludzkiego umysłu.

\section{Hipotezy}

Przyjęcie powyższych wstępnych założeń na temat fenomenu sztuki oraz jej teoretycznych ujęć pozwala wskazać na uniwersalny charakter sztuki oraz jej niezbywalność, ,jako daru od naszych przodków, świadectwa ich umiejętności i życia emocjonalnego"66 — a także poddać sprawdzeniu następujące hipotezy:

1. Sztuka wywołuje emocje na równi z adaptacyjnymi mechanizmami ludzkiego umysłu, takimi jak moduł detekcji oszusta czy zdolność do widzenia głębi ${ }^{67}$, ponieważ miała znaczenie adaptacyjne, a więc przyczyniła się do zwiększenia tak zwanej zdolności przystosowawczej (inclusive fitness) organizmów naszych przodków (i być może nas samych) (rozdział 2).

2. Uniwersalizm preferencji estetycznych ujawnionych między innymi w malarstwie krajobrazowym oraz w eksperymencie Komara i Melamida odzwierciedla adaptacyjny walor wyboru siedliska, zgodnie z koncepcją EEA (Environment of Evolutionary Adaptiveness) ${ }^{68}$, oraz naturalną ludzką skłonność do kiczowatych pejzaży (a przy okazji zwraca uwagę na antynaturalizm sztuki modernistycznej) (rozdział 2).

3. Uniwersalność sztuki (fakt, że nie istnieją kultury niewytwarzające jakiejś formy sztuki oraz że rozpoznajemy sztukę bez pomocy teoretyków) i jej odbioru (upodobanie do ponadczasowej sztuki „wielkich mistrzów” - Peruwiańczycy kochają japońskie drzeworyty, włoska opera podoba się w Chinach, a Szekspir został przetłumaczony na wszystkie ważniejsze języki świata) można wyjaśnić, uznając ją za rodzaj naturalny i stosując kryteria rozpoznawcze (recognition criteria), dobrane na zasadzie definicji skupiskowej (cluster definition) sztuki lub homeostatycznej wiązki własności (rozdział 3 i 4).

65 Por. B. Boyd, On the Origin of Species; S. Davies, The Artful Species: Aesthetics, Art, and Evolution, Oxford 2012, s. 25-34.

66 D. Dutton, A Darwinian Theory of Beauty, „Philosophy and Literature” 38 [1A] (2014), s. A318.

67 Por. E. Dissanayake, What is Art For?, Seattle 1988; S. Pinker, Jak działa umyst; D. Buss, Psychologia ewolucyjna; J. Tooby, L. Cosmides, Conceptual Foundations of Evolutionary Psychology, [w:] The Handbook of Evolutionary Psychology, D. Buss (ed.), Hoboken, NJ 2005, s. 5-67.

68 Por. G.H. Orians, J.H. Heerwagen, Evolved Responses to Landscapes, [w:] The Adapted Mind: Evolutionary Psychology and the Generation of Culture, J.H. Barkow, L. Cosmides, J. Tooby (eds.), New York, NY 1992, s. 555-580; i inne teksty w tej książce; Paintings by Numbers: Komar and Melamid's Scientific Guide to Art, J. Wypijewski (ed.), New York 1997, s. 124-140; E. Dissanayake, What is Art For?; D. Dutton, Instynkt sztuki. 
4. Śledząc dzieje refleksji estetycznej, nietrudno jest dostrzec, jak bardzo badanie sztuki — tego uniwersalnego ludzkiego fenomenu — zdominowane jest przez liczne tendencje antyuniwersalistyczne, takie jak: a) problemy i debaty estetyczne ograniczone do danej epoki historycznej i związanych z nią prądów artystycznych i kulturowych, b) wpływ indywidualnych (często na wskroś subiektywnych) preferencji estetycznych poszczególnych filozofów na tworzenie przez nich teorii estetycznych, roszczących sobie prawo do obiektywności (na przykład nakładanie norm estetycznych jednego rodzaju sztuki na inny), c) a także charakter filozoficznej retoryki, który naraża teorie na dezinterpretacje. Przykładem może być obsesja współczesnych estetyków na punkcie tak zwanych przypadków granicznych w sztuce (dadaizm, abstrakcja, cisza w muzyce i in.), wyrażająca się w praktyce tworzenia nowych teorii na potrzeby i pod wpływem nowych, zaskakujących zjawisk artystycznych. Wątpliwość co do trafności takiej strategii można wykazać poprzez analogię do maksymy prawniczej, mówiącej, że „trudne przypadki tworzą złe prawo" $" 69$. Ewolucyjne badanie sztuki może stanowić skutecznie antidotum na takie ,źle" zaprojektowane, ale najczęściej po prostu nieciekawe poznawczo, teorie (rozdział 5).

5. Istnienie uniwersaliów estetycznych — międzykulturowych i ponadhistorycznych kryteriów sztuki oraz jej oceny — znajduje potwierdzenie w krytyce etnocentryzmu (z jednej strony: antropologii kulturowej, jako dyscypliny, która uznaje, że pojęcie sztuki jest nieprzekładalne i uniemożliwia estetyczną klasyfikację wytworów artystycznych innych kultur, z drugiej zaś poglądów niektórych estetyków, twierdzących, że uznanie czegoś za sztukę jest kwestią interpretacji lub teorii). Tworzenie sztuki w społecznościach pierwotnych miało zawsze charakter percepcyjno-zmysłowy i, jak się wydaje, na podstawie takich kryteriów odbywała się zwykle jej ocena (rozdział 5).

6. Niektóre kategorie estetyczne (kunsztu, biegłości, wirtuozerii, reprezentacji, wyobraźni) otrzymują mocny fundament w postaci badań empirycznych nauk szczegółowych, potwierdzających ich uniwersalny i ewolucyjny charakter (rozdział 5 i 6).

7. Przyjęcie perspektywy uniwersalistycznej i naturalistycznej w estetyce nie oznacza jeszcze automatycznie uznania sztuki (lub poszczególnych sztuk) ${ }^{70}$ za efekt doboru naturalnego, czy to w postaci adaptacji, czy produktu ubocznego, nie przybliża nas też do wyjaśnień sztuki w terminach doboru płciowego. Warunkiem niezbędnym zbadania, czy dana cecha lub zachowanie (w tym zachowanie artystyczne czy artyfikacyjne) są adaptacyjne w sensie biologicznym jest odwołanie się: po pierwsze, do badań empirycznych prowadzonych z zastosowaniem metod nauk przyrodniczych, a ściślej rzecz biorąc, z zastosowaniem teorii doboru naturalnego; po drugie, nieustanne uwzględnianie czterech wielkich pytań Tinbergena ${ }^{71}$ :

69 Por. The Forger's Art: Forgery and the Philosophy of Art, D. Dutton (ed.), Berkley-Los Angeles 1983; D. Dutton, Instynkt sztuki.

70 Niezwykle istotne rozróżnienie dla badań nad ewolucyjną funkcją sztuki; warto odwołać się tu do ciekawych analiz Daviesa (2012) oraz Seghers (więcej na ten temat w rozdziale 7 mojej książki, przy okazji omówienia zarzutów formułowanych wobec metodologii podejścia ewolucyjnego w estetyce).

71 N. Tinbergen, On aims of ethology, "Zeitschrift fur Tierpsychologie” 20 (1963), 410-433; por. D. Buss, Psychologia ewolucyjna, s. 33-34. 
a) o bezpośrednie przyczyny zachowania,

b) jego przyczyny rozwojowe,

c) motywacje, towarzyszące zachowaniu, a więc cel adaptacyjny, który wydają się one spełniać, oraz

d) jego ewolucyjne lub filogenetyczne źródła.

Dopiero stosowanie się do tak zarysowanego protokołu pozwala unikać pułapek w rodzaju just so stories oraz nie narażać się ,na ryzyko rozwijania wyjaśnień post hoc, w których będziemy wybierać tylko te przykłady, które wspierają nasze wyjaśnienie, a ignorować te, które tego nie robią"72 (rozdział 7).

\section{„Prawdziwie znaturalizowany opis"}

Zważywszy na to, że w ujęciu analitycznym podstawowym przedmiotem badań filozofii sztuki są przekonania na temat sztuki, a jedynie wtórnie bada ona obiekty określane nazwą, ,sztuka”, w swojej pracy staram się pokazać, że interdyscyplinarność ewolucyjnego podejścia do problemów estetycznych możliwa jest dzięki naturalizacji perspektywy estetyczno-filozoficznej oraz „zwrotu etologicznego” w estetyce. Dążenie do wyjaśnienia tajemnic związanych z pochodzeniem, źródłami i funkcją sztuki i zachowań artystycznych w sytuacji bezprecedensowych odkryć nauk ewolucyjnych o kulturze i poznaniu postrzegam jako swoistą powinność badacza, któremu leży na sercu znalezienie odpowiedzi na odwieczne pytania o prawdziwą naturę sztuki i wywoływanych przez nią emocji. Nieobcy jest mi również optymizm badawczy, towarzyszący studiom ewolucyjnym (w tym również studiom nad sztuką), którego charakter najlepiej chyba oddaje fragment wypowiedzi Francisca Ayali:

Zasadniczo nieograniczony zasób informacji ewolucyjnej, zakodowanej w sekwencjach DNA żywych organizmów, pozwala ewolucjonistom rekonstruować wszelkie ewolucyjne stosunki wiodące do obecnych organizmów z dowolną wymaganą liczbą szczegółów. Jeżeli zainwestuje się niezbędne środki (czas i wydatki na prace laboratoryjne), można uzyskać odpowiedzi na wszelkie możliwe pytania z dowolną precyzją $^{73}$

Jak jednak wykorzystać tę bogatą interdyscyplinarną wiedzę w teorii, unikając zarówno wielu pułapek metodologicznych, jak i oporu środowiska?

Odpowiedź podsuwa Dutton, jeden z bohaterów mojej monografii. Wydaje się on świadom faktu, że wielu filozofów (a pomiędzy nimi wielu estetyków) jest niechętnych psychologizowaniu wartości, zwłaszcza jeżeli oznacza to ich naturalizowanie jako trwałego składnika ewoluującej natury ludzkiej. Pyta jednak: „Cóż lepszego jest w używaniu »kultury « jako uniwersalnego wytłumaczenia dla wartości?" i postuluje „prawdziwe znaturalizowany” i przez to darwinowski opis doświadczenia

72 M. Scalise Sugiyama, Carving Art Behavior at the Joints: Symbolic Behavior, Aesthetic Responses, and Artification, „ASEBL Journal” 11 [2] (2015), s. 47.

73 F. Ayala, 5 Questions for Francisco Ayala (Evolutionary Biologist 8 Britannica Contributor) on Charles Darwin 83 His Legacy, http://blogs.britannica.com/2009/02/an-interview-with-francisco-ayala-evolutionary-biologist-britannica-contributor-on-charles-darwin-his-legacy/ (dostęp: 28.12.2017), za: A. Chmielewski, Estetyka ewolucyjna jako platforma interdyscyplinarna, [w:] Interdyscyplinarnie o interdyscyplinarności. Między idea a praktyka, A. Chmielewski, A. Dudziakowa, A. Grobler (red.), Kraków 2012, s. 273.

Studia Philosophica Wratislaviensia vol. XVI, fasc. 1, 2021

(C) for this edition by CNS 
estetycznego, który ,[...] powinien być do pewnego stopnia spekulatywny, przyjmując jednak ze szczególnym zadowoleniem dowód empiryczny w postaci wyników badań psychologów ewolucyjnych", który mógłby prowadzić do potwierdzenia lub zdecydowanego obalenia wysuwanych hipotez. „Nie stałoby to, jego zdaniem, w opozycji do opisów doświadczenia estetycznego w terminach niepowtarzalnej ekspresji kulturowej, ale wzmacniałoby je poprzez umiejscowienie ich w perspektywie uniwersalnej”"74. Jak słusznie argumentuje: ,[...] naukowe językoznawstwo nie redukuje olbrzymiej różnorodności języków ludzkich do pojedynczego zubożałego kodu, więc również naukowa, znaturalizowana estetyka nie redukowałaby sztuki do czegokolwiek mniejszego niż bogata, życiodajna siła, którą sztuka jest""75.

Uzasadniając adekwatność poszczególnych hipotez, korzystam zatem, częściowo za namową Duttona, z narzędzi teoretycznych filozofii sztuki w nurcie analitycznym (między innymi definicji pojęcia sztuki od Władysława Tatarkiewicza przez Berysa Gauta po Stephena Daviesa i Arthura Danto, kategorii kunsztowności Jorome'a Stolnitza czy stanowiska perceptualizmu estetycznego Monroe C. Beardsleya) oraz dokonań nauk ewolucyjnych (od Karola Darwina przez Edwarda O. Wilsona i Stevena Pinkera po Geoffreya Millera i Desmonda Morrisa). Poruszam się w obrębie pola badawczego kreślonego przez autora Instynktu sztuki (nie ograniczając się jednak wyłącznie do niego; rozszerzam je dzięki inspirującemu wpływowi Ellen Dissanayake, Michelle Scalise Sugiyamy, Josepha Carrolla i Daviesa), którego zajmowały między innymi: problemy fałszerstw w sztuce, intencjonalizmu w teorii i praktyce artystycznej oraz kwestie statusu estetycznego dzieł sztuki plemiennej i dzieł dadaistycznych, a także tak zwane przypadki graniczne sztuki — sportu widowiskowego, praktyk zdobienia ciała, rękodzieła czy sztuki dekoracyjnej, a które wypracował na długo przed tym, jak zainteresował się perspektywą ewolucyjną.

W znacznej mierze podzielam jego stanowisko naturalistyczne, choć staram się w pełni oddawać sens argumentów wobec niego krytycznych; postrzegam je jako konsekwentną realizację programu „trzeciej kultury” (więcej na ten temat piszę w rozdziale 1) i uważam za odważny, szeroko zakrojony, a jednocześnie spójny i porządkujący projekt filozoficzno-estetyczny, powstający w obrębie obiecującej, młodej dyscypliny, jaką jest estetyka ewolucyjna (ewolucyjne podejście do sztuki) ${ }^{76}$; dyscypliny, której najbardziej znamienną cechą jest niezamykanie się na potoczny, przedteoretyczny ogląd sztuki, czyli poszukiwanie uniwersalnego, międzykulturowego podłoża różnych sztuk, badanie tego, co jest realnym składnikiem rzeczywistości przy użyciu optyki uniwersaliów oraz rzetelne stosowanie się do protokołu naukowego. Znacznym osiągnięciem Duttona jest też ożywienie tradycyjnych kategorii estetycznych: biegłości, wirtuozerii, kunsztu, piękna i wyobraźni, zwrócenie uwagi na rolę emocji, przyjemności i zachwytu w doświadczeniu estetycznym oraz nadanie im empirycznego umocowania w wynikach badań naukowych.

${ }^{74}$ D. Dutton, Znaturalizujmy estetyke, tłum. J. Luty, http://www.racjonalista.pl/kk.php/s,6870 (dostęp: 12.04.2021).

${ }^{75}$ Ibidem.

${ }^{76}$ Ewolucyjny projekt Duttona nie jest jedyny, nie jest też w pełni oryginalny (choć na gruncie estetyki filozoficznej jest w znacznej mierze i wyjątkowy, i oryginalny). Najważniejsze źródła jego inspiracji (nie licząc psychoewolucyjnych - Pinkera, Millera, E.O. Wilsona) to etologiczno-estetyczne stanowisko Ellen Dissanayake i literaturoznawczy darwinizm Josepha Carrolla.

Studia Philosophica Wratislaviensia vol. XVI, fasc. 1, 2021

(C) for this edition by CNS 


\section{Krytyki, wyzwania, perspektywy}

Pomimo bogactwa hipotez, odnoszaccych się do adaptacyjnej funkcji sztuki i zachowań artystycznych, warto zwrócić również uwagę na liczne ograniczenia estetyki ewolucyjnej, które w pewnej mierze pokrywają się z ograniczeniami samego programu psychoewolucyjnego ${ }^{77}$.

Sztuka jako przedmiot badań empirycznych pojawia się w jego obrębie wciąż stosunkowo rzadko. Estetyka ewolucyjna jako młoda i obiecujacca dyscyplina nadal w zasadzie nie ma wypracowanej metodologii, choćby takiej jak neuroestetyka. Niewielka liczba badań empirycznych, testujacych istniejace hipotezy (przede wszystkim z zakresu antropologii fizycznej i archeologii kognitywnej) dotyczace adaptacyjnych walorów sztuki powoduje, że większość twierdzeń estetyki ewolucyjnej pozostaje w fazie hipotez. Jeszcze do niedawna nie istniały też żadne wszechstronne dane porównawcze zachowań estetycznych (czy protoestetycznych) Homo sapiens i przedstawicieli innych gatunków człowieka, co na szczęście zmieniło się za sprawą ostatnich wspaniałych odkryć związanych ze sztuką neandertalską.

Wciąż dyskutowane są kwestie natury i mechanizmów funkcjonowania modułów umysłowych, co z kolei wiąże się z nieustanną krytyką wysuwaną pod adresem psychologii ewolucyjnej za jej jednowymiarowe ujęcie kultury. Z kolei spory wokół tego, kiedy dane zachowanie artystyczne można uznać za adaptację (a może produkt uboczny adaptacji lub twór wyłącznie kulturowy), nie prowadzą do jasnych konkluzji, co wynika z faktu, że otrzymywane wyniki badań można często przypisać do wielu hipotetycznych funkcji. Na przykład jeśli hipoteza o tym, że dane zachowanie jednoczy ludzi, zostanie potwierdzona empirycznie, to i tak nie musi oznaczać, że zachowanie to jest adaptacją. Aby wyjaśnienie ewolucyjnego pochodzenia zachowania było wiarygodne, powinno ono przejść wspomniany test Tinbergena (1951), a więc uzyskać potwierdzenie w każdym z czterech aspektów:

1. powinno ujawniać się spontanicznie na wczesnym etapie rozwoju osobniczego (spontaniczne gaworzenie u niemowląt czy przyjemność w rysowaniu lub pozostawianiu znaków);

2. posiadać zidentyfikowaną funkcję (stanowisko Duttona nie jest tu jednoznaczne; sztuka jest po to, aby czytać w umysłach innych i zachwycać się nimi, ale też po to, aby uwieść najlepszą partię w okolicy; z kolei Dissanayake nie ma wątpliwości, że artyfikacja służy nadawaniu rzeczom i zdarzeniom ,szczególnego charakteru" i jest zachowaniem adaptacyjnym) oraz

3. historię ewolucyjną (kompleksowo kreśli ją zarówno Dissanayake, jak i Scalise Sugiyama);

4. mieć mechanizm emocjonalny wywołujący przyjemność lub odrazę, który uruchamia się w określonych okolicznościach (coś, w czym sztuka miałaby się specjalizować, ale też coś, w czym nic innego poza sztuką specjalizować się nie powinno;

77 Por. S. Davies, The Artful Species; S. Davies, Response to Wilfried van Damme, Ellen Dissanayake, Joseph Carroll, Katja Mellmann, and Jerzy Luty, ,Estetika: The Central European Journal of Aesthetics" 51 [7] (2014), s. 126-136; E. Seghers, The Artful Mind: A Critical Review of the Evolutionary Psychological Study of Art, „The British Journal of Aesthetics” 55 [2] (2015), s. 225-248; M. Portera, Toward an Integrated Science of Aesthetics. Getting Rid of the Main Misunderstandings in Evolutionary Aesthetics, „Aisthesis. Pratiche, linguaggi e saperi dell'estetico” 8 [1] (2015), s. 194-203. 
czy sztuka jest aż tak swoistą aktywnością? Dość wątpliwe, aby była nią sztuka wysoka, ale rozszerzone, etologiczne pojęcie sztuki zaproponowane przez Dissanayake może taki warunek spełniać; być może jest nią muzyka tonalna). Jeśli każdy z tych warunków zostanie spełniony, z dużą dozą pewności można stwierdzić, że badane zachowanie jest adaptacją w sensie ścisłym. Czy jednak ścisłość jest domeną sztuki?

Z punktu widzenia teoretyka i filozofa sztuki najbardziej interesujacce poznawczo w rozważaniach estetyczno-ewolucyjnych pozostają dwie kwestie: problem wiarygodności naukowej hipotez ewolucyjnych oraz kwestia zmian w obrębie pojęcia sztuki, zachodzących pod wpływem perspektywy ewolucyjnej. Uważam, że estetyczna perspektywa uniwersalistyczna wsparta badaniami ewolucyjnymi ze znacznym powodzeniem powoduje przeformułowanie pojęcia sztuki. Z jednej strony przywraca je do życia po postmodernistycznej dewaluacji, pokazując, w jaki sposób tworzyć teorię sztuki bez redukowania jej przedmiotu do kultury, stylu, teorii czy interpretacji, poprzez eksplorowanie pewnych uniwersalnych motywów i heurystyk, będących rewersem jego naturalnego źródła - ludzkiego umysłu. Z drugiej strony, przez odniesienie do kategorii kunsztu, biegłości i wirtuozerii oraz kategorii przyjemności, wywołuje dawno niewidzianą konfuzję: sztuka to już nie tylko obiekty czy działania, lecz także formy ludzkiego zachowania (mające walor adaptacyjny). Podejście etologiczne sprawia ponadto, że pojęcia artification, making special czy signaling okazują się wyzwaniem na miarę kryzysu pojęciowego w teorii sztuki, obserwowanego przez Tatarkiewicza już w latach pięćdziesiątych XX wieku.

Jak sądzę, współczesne podejście do analizy sztuki przybiera zwykle dwa skrajne oblicza: z jednej strony jest estetyka tradycyjna, która nie przejmuje się uniwersalizmem sztuki, tworzy coraz bardziej rozbudowane teorie estetyczne, które nie próbują nawet dociekać międzykulturowego charakteru doświadczenia estetycznego. Najlepszym przykładem jest tu koncepcja Arthura Danto, który na przykład twierdzi, że sztuka plemienna jest dla nas niepoznawalna tak długo, jak nie przyłożymy do niej zachodnich standardów estetycznych (rozdział 3 i 5). Z drugiej strony mamy do czynienia z prężnym rozwojem neuroestetyki, której cechą szczególną jest to, że znacznie redukuje samo pojęcie sztuki. Z tego powodu, wielu autorów gotowych jest twierdzić, że perspektywa biologiczna i humanistyczna pozostają nie do pogodzenia. Czy rzeczywiście?

Mimo pewnych ograniczeń, o których wspomniałem, ewolucyjne badanie sztuki i zachowań artystycznych spełnia istotną rolę — wskazuje na ich niezbywalność „jako ogólnie akceptowanego i pożądanego dobra”. „[Sztuka] daje nam możliwość zajrzenia w głąb ludzkiej duszy, pomaga w szybszym dochodzeniu do zdrowia, pozwala bardziej docenić świat natury. Może sprzyjać tworzeniu się społeczności lub przeciwnie, ukazać zalety kultywowania indywidualności. Sztuka może pocieszyć w czasie kryzysów życiowych, może ukoić nerwy, pomóc w osiągnięciu psychologicznego katharsis, wyzwalać emocje, które oczyszczają umysł i karmią duszę"78.

Sztuka operuje zatem w ramach naturalnego, niezmiennego, uniwersalnego dla wszystkich ludzi aparatu doznań. Wywołuje emocje porównywalne z adaptacyjnymi mechanizmami ludzkiego umysłu, takie jak: zachwyt, przyjemność, podziw,

78 D. Dutton, Instynkt sztuki, s. 155. 
strach, zaskoczenie, odraza. Być może przyczyniła się do zwiększenia zdolności przystosowawczej naszych przodków, pomagając im na wielu poziomach. Wskazuje na to odziedziczona po nich swoista „uniwersalna gramatyka”, wielofunkcyjny organ — ,instynkt sztuki”, który jest skomplikowanym zbiorem impulsów — podinstynktów. Obejmuje on nasze reakcje na szerokie spektrum zjawisk (środowisko naturalne, potencjalne zagrożenia i sposoby radzenia sobie z nimi, kolory i dźwięki, erotyzm i kosztowność, wyzwania intelektualne i te, dotyczące osiągania statusu społecznego, trudności techniczne, oraz nasze głębokie zainteresowaniem osobowością drugiego człowieka-artysty, czemu towarzyszy nieustanny podziw dla prezentowanych przez niego biegłości i wirtuozerii). Uniwersalizm sztuki i preferencji estetycznych ujawnia się między innymi w malarstwie krajobrazowym na wzór pejzaży z eksperymentu Komara i Melamida, ale również w tym, że różne formy sztuki rozpoznajemy bez pomocy teoretyków. To z kolei pozwala nam uznać sztukę za rodzaj naturalny, a więc opisać ją w taki sam sposób, w jaki opisujemy minerały, gatunki biologiczne czy choroby psychiczne.

Wydaje się zatem, że estetyka ewolucyjna z powodzeniem może wypełnić niezagospodarowaną przestrzeń między biologią a humanistyką, stać się swoistą platformą interdyscyplinarną ${ }^{79}$, która, posiłkując się naukami ewolucyjnymi, z pełną powaga traktuje tradycyjne problemy estetyczne (funkcje i wartość sztuki; granice sztuki, intencjonalność, esencjalizm) i próbuje je rozstrzygać, korzystając z danych empirycznych wielu dziedzin. W swojej monografii staram się również dowieść tezy, że wyjątkowa idea konsiliencji nauk humanistycznych i przyrodniczych, pomimo pewnych wątpliwości metodologicznych, w badaniach estetyków ewolucyjnych - Denisa Duttona, Ellen Dissanayake, Stephena Daviesa, Josepha Carrolla, Michelle Scalise Sugiyamy czy Briana Boyda — znajduje atrakcyjną, z punktu widzenia współczesnych uniwersalistycznych wyzwań, wykładnię. Przybliża nas też do zrozumienia wyjątkowości człowieka — jedynego gatunku, który nie tylko powszechnie tworzy i konsumuje sztukę, ale jest w niej bezgranicznie rozmiłowany.

\section{Bibliografia}

Aiken N.E., The Biological Origins of Art, Westport, CT 1998.

Ayala F., 5 Questions for Francisco Ayala (Evolutionary Biologist 86 Britannica Contributor) on Charles Darwin \& His Legacy, http://blogs.britannica.com/2009/02/ an-interview-with-francisco-ayala-evolutionary-biologist-britannica-contributor-oncharles-darwin-his-legacy/ (dostęp: 28.02.2021).

Biologia atrakcyjności człowieka, B. Pawłowski (red.), Warszawa 2009.

Borczyk B., Korzenie wspótczesnego antyewolucjonizmu, [w:] Ewolucja. Filozofia. Religia, D. Leszczyński (red.), (Lectiones \& Acroases Philosophicae III), Wrocław 2010, s. $85-107$.

Boyd B., On the Origin of Stories: Evolution, Cognition, and Fiction, Cambridge, Mass. 2009.

79 Por. A. Chmielewski, Estetyka ewolucyjna jako platforma interdyscyplinarna. 
Boyer P., I człowiek stworzył bogów... Jak powstała religia?, tłum. K. Szeżyńska-Maćkowiak, Warszawa 2005.

Brockman J., Wstęp. Nowy Renesans, [w:] Nowy Renesans: granice nauki, J. Brockman (red.), tłum. P.J. Szwajcer, A. Eichler, Warszawa 2005, s. 9-20.

Buss D., Psychologia ewolucyjna, tłum. M. Orski, Gdańsk 2001.

Carroll J., An Evolutionary Paradigm for Literary Study, ,Style” 42 [2] (2008), s. 103-135.

Carroll J., Reading Human Nature: Literary Darwinism in Theory and Practice, Albany, NY 2011.

Chmielewski A., Estetyka ewolucyjna jako platforma interdyscyplinarna, [w:] Interdyscyplinarnie o interdyscyplinarności. Między idea a praktyka, A. Chmielewski, A. Dudziakowa, A. Grobler (red.), Kraków 2012, s. 273-290.

Churchland P.S., Braintrust: What Neuroscience Tells Us about Morality, Princeton 2011. Churchland P.S., Neurophilosophy: Toward a Unified Science of the Mind-Brain, Cambridge, Mass. 1989.

Coe K., The Ancestress Hypothesis, New York 2003.

Cosmides L., Tooby J., Evolutionary psychology: Foundational papers, Cambridge, Mass. 2000.

Cronin H., Adaptation: A Critique of Some Current Evolutionary Thought, „The Quarterly Review of Biology" 80 [1] (2005), s. 19-26.

Daly M., Wilson M., Homicide, New York 1988.

Darwin K., O powstawaniu gatunków, tłum. S. Dickstein, J. Nusbaum, Warszawa 2009.

Davies S., The Artful Species: Aesthetics, Art, and Evolution, Oxford 2012.

Davies S., Response to Wilfried van Damme, Ellen Dissanayake, Joseph Carroll, Katja Mellmann, and Jerzy Luty, „Estetika: The Central European Journal of Aesthetics” 51 [1] (2014), s. 126-136.

Davies S., Why Art Is not a Spandrel, „British Journal of Aesthetics” 50 [4] (2010), s. $333-341$.

Dawkins R., Fenotyp rozszerzony. Dalekosiężny gen, tłum. J. Gliwicz, Warszawa 2007.

Dawkins R., Samolobny gen, tłum. M. Skoneczny, Warszawa 1996.

Dennett D., Odczarowanie. Religia jako zjawisko naturalne, tłum. B. Stanosz, Warszawa 2008.

Dissanayake E., Art and Intimacy. How the Arts Began, Seattle 2000.

Dissanayake E., Homo Aestheticus: Where Art Comes From and Why, Seattle 1995.

Dissanayake E., What is Art For?, Seattle 1988.

Dunbar R., Pchły, plotki a ewolucja języka, tłum. T. Pańkowski, Warszawa 2009.

Dutton D., A Darwinian Theory of Beauty, „Philosophy and Literature" 38 [1A] (2014), s. A314-A318.

Dutton D., Epilog. Nowy Renesans, [w:] Nowy Renesans, J. Brockman (red.), tłum. P.J. Szwajcer, A. Eichler, Warszawa 2005, s. 390-393.

Dutton D., Instynkt sztuki. Piękno, zachwyt i ewolucja człowieka, tłum. J. Luty, Kraków 2019.

Dutton D., Znaturalizujmy estetyke, tłum. J. Luty, http://www.racjonalista.pl/kk.php/ s,6870 (dostęp: 12.04.2021).

The Forger's Art: Forgery and the Philosophy of Art, D. Dutton (ed.), Berkley-Los Angeles 1983.

Studia Philosophica Wratislaviensia vol. XVI, fasc. 1, 2021

(C) for this edition by CNS 
Gould S.J., Lewontin R.C., Pendentywy w katedrze św. Marka a paradygmat Panglossa. Krytyka programu adaptacyjnego, tłum. K. Bielecka, „Przegląd Filozoficzno-Literacki" $2 / 3$ [31] (2011), s. 63-85.

Hagberg G.L., Introductory Note: Denis Dutton, editor, „Philosophy and Literature”, Evolutionary Aesthetics: A Special Issue in Memory of Denis Dutton, 38 [1A] (2014), s. iv-vi.

Hamer D., The God Gene: How Faith Is Hardwired into Our Genes, New York 2004.

Hauser M., Moral Minds: How Nature Designed a Universal Sense of Right and Wrong, New York 2006.

Hohol M., Wyjasnić umyst. Struktura teorii neurokognitywnych, Kraków 2013.

Luty J., Estetyka ewolucyjna, „Biuletyn Polskiego Towarzystwa Estetycznego” 18 (2011), s. $16-17$.

Luty J., Estetyka ewolucyjna: sztuka jako adaptacja w ujęciu międzykulturowym, „Estetyka i Krytyka" 21 (2011), s. 99-112.

Luty J., Sztuka jako adaptacja: uniwersalizm w estetyce ewolucyjnej, Kraków 2018.

McNamara P., The Neuroscience of Religious Experience, Cambridge 2009.

Mellmann K., Evolutionary Psychology as a Heuristic in Literary Studies, [w:] The Evolution of Literature. Legacies of Darwin in European Cultures (Internationale Forschungen zur Allgemeinen und Vergleichenden Literaturwissenschaft 152), N. Saul, S.J. James (eds.), Rodopi 2011, s. 299-317.

Miller G., Umysł w zalotach: jak wybory seksualne kształtowały nature człowieka, tłum. M. Koraszewska, Poznań 2004.

Miłkowski M., Perspektywy ewolucjonistyczne w badaniach społecznych, [w:] Oprogramowanie rzeczywistości społecznej, M. Gdula, L.M. Nijakowski (red.), Warszawa 2014, s. $185-208$.

Nowy Renesans: granice nauki, J. Brockman (red.), tłum. P.J. Szwajcer, A. Eichler, Warszawa 2005.

Orians G.H., Heerwagen J.H., Evolved Responses to Landscapes, [w:] The Adapted Mind: Evolutionary Psychology and the Generation of Culture, J.H. Barkow, L. Cosmides, J. Tooby (eds.), New York, NY 1992, s. 555-580.

Paintings by Numbers: Komar and Melamid's Scientific Guide to Art, J. Wypijewski (ed.), New York 1997, s. 124-140.

Pinker S., Toward a Consilient Study of Literature (review of J. Gottschall \& D. Sloan Wilson, "The Literary Animal: Evolution and the Nature of Narrative”, „Philosophy and Literature" 31 [1] (2013), s. 161-177.

Pinker S., Jak działa umyst, tłum. M. Koraszewska, Warszawa 2002.

Pinker S., Tabula rasa. Spory o nature ludzka, tłum. A. Nowak, Gdańsk 2005.

Pinker S., Bloom P., Natural language and natural selection, „Behavioral and Brain Sciences" 13 [4] (1990), s. 707-784.

Portera M., Toward an Integrated Science of Aesthetics. Getting Rid of the Main Misunderstandings in Evolutionary Aesthetics, „Aisthesis. Pratiche, linguaggi e saperi dell'estetico" 8 [1] (2015), s. 194-203.

Ridley M., O pochodzeniu cnoty, tłum. M. Koraszewska, Poznań 2000.

Ryszkiewicz M., Nie mieszajcie w to Darwina, „Gazeta Wyborcza” 6.02.2013. 
Salmon C., Symons D., Warrior Lovers: Erotic Fiction, Evolution and Female Sexuality, London 2001.

Scalise Sugiyama M., Carving Art Behavior at the Joints: Symbolic Behavior, Aesthetic Responses, and Artification, „ASEBL Journal” 11 [2] (2015), s. 43-47.

Seghers E., The Artful Mind: A Critical Review of the Evolutionary Psychological Study of Art, „The British Journal of Aesthetics” 55 [2] (2015), s. 225-248.

Snow C.P., Dwie kultury, tłum. T. Baszniak, Warszawa 1999.

Thornhill R., Palmer C.T., Rape: A Natural History of Biological Bases of Coercion, Cambridge, Massachusetts 2000.

Tinbergen N., On aims of ethology, "Zeitschrift fur Tierpsychologie" 20 (1963), s. 410-433.

Tooby J., L. Cosmides, Conceptual Foundations of Evolutionary Psychology, [w:] The Handbook of Evolutionary Psychology, D. Buss (ed.), Hoboken, NJ 2005, s. 5-67.

Trivers R., The Evolution of Reciprocal Altruism, „The Quarterly Review of Biology" 46, [1] (1971), s. 35-57.

Trivers R., Deceit and Self-Deception. Fooling Yourself the Better to Fool Others, London 2011.

Trzecia kultura, Brockman J. (red.), tłum. P. Amsterdamski et al., Warszawa 1996.

Vetulani J., Mózg: fascynacje, problemy, tajemnice, Kraków 2010.

Voland E., Preferencje estetyczne w świecie artefaktów - przystosowanie do osadu „uczciwych sygnałów”, tłum. J. Luty, „Przegląd Filozoficzno-Literacki” 2/3 (2011), s. 299-323.

Wallace A.R., Contributions to the Theory of Natural Selection, London 1870.

Weiss M., Etyka a ewolucja. Metaetyczny kontekst etyki ewolucyjnej, Poznań 2011.

Williams G.C., Adaptation and Natural Selection: A critique of Some Current Evolutionary Thought, Princeton 1966.

Zahavi A., Zahavi A., The Handicap Principle - A Missing Piece of Darwin's Puzzle, New York 1997.

Zeki S., Inner Vision. An Exploration of Art and the Brain, Oxford 1999.

Żywiczyński P., Wacewicz S., Ewolucja języka. W stronę hipotez gesturalnych, Toruń 2015.

Studia Philosophica Wratislaviensia vol. XVI, fasc. 1, 2021

(C) for this edition by CNS 